\title{
Nature conservation as if people mattered
}

\author{
James Aronson ${ }^{a, b}$, Sue J. Milton ${ }^{c, d}$, James N. Blignaut ${ }^{e}$, \\ Andre F. Clewell ${ }^{f}$
}

\author{
${ }^{\mathrm{a}}$ Restoration Ecology Group, CEFE (CNRS-UMR 5175), Montpellier, France \\ ${ }^{\mathrm{b}}$ Missouri Botanical Garden, USA \\ ${ }^{c}$ Conservation Ecology Department, University of Stellenbosch, South Africa \\ ${ }^{d}$ The FitzPatrick Institute, University of Cape Town, South Africa \\ ${ }^{e}$ Department of Economics, University of Pretoria, Lynnwood Road, Pretoria 0002, South Africa \\ ${ }^{f}$ A.F Clewell, Inc., 5351 Gulf Drive \#5, Holmes Beach, FL 34217-1954, USA
}

\begin{abstract}
Summary
The restoration of natural capital is arguably one of the most radical ideas to emerge in recent years as it links two imperatives whose exponents have been at loggerheads for decades. These are the need to protect biodiversity and conserve natural resources as espoused by conservationists and environmentalists, and the demand for natural resources as dictated by economists and society at large, at local, regional, national and international scales. We need to work together, or even 'leap together', across traditional disciplinary frontiers or polemical stances, in order to find innovative solutions that counter the prevailing ideological divide separating economics and ecology. We close this special issue with a proposition of five pillars and three principal tasks for sustainable living, including conservation and restoration.
\end{abstract}

KEYWORDS: Conservation science; Ecological restoration; Natural Capital; Social Capital; Sustainability

In just two centuries, we humans have transformed terrestrial and marine ecosystems on our planet and have seriously reduced their flows of life-essential goods and services (Millennium Ecosystem Assessment 2005). We are now in a situation of ecological overshoot (Wackernagel \& Rees 1997). Our own welfare, the survival of other species and the resilience of the global life-support systems, are all at risk. Furthermore, the welfare of the majority of people - and therefore of humanity -has actually declined in the past 35 years (Saul 2005). What does this mean for conservation science and practice? More than ever, it means that people are part of nature and we must practice ecological conservation - and restoration - as if people mattered too.

At long last, not only conservation biologists and environmentalists, but also economists, politicians and business leaders are questioning the efficacy of the prevailing economic paradigms (e.g. Arrow, Bolin, \& Costanza 1995; Blignaut 2004; Dasgupta 2002; Heal 2000), and the future of the globalised, consumerism-based capitalist economic system that it legitimises (Saul 2005). The time has come for a unified effort to solve holistically the inextricable problems of people, the rest of Nature, and our mutually interdependent economic systems. Conservation science and the wise use and management of protected areas are integral to this solution, as is ecological restoration, which is our only real hope of augmenting the planetary inventory of natural areas.

Restoration ecology is a one of the keys to the future of conservation science (Dobson, Bradshaw, \& Baker 1997; MacMahon \& Holl 2001; Young 2000). As we suggested in the opening essay, both are part of something bigger, i.e. sustainability science (Kates, Clark, \& Corell 2001) and management. Ecologists and economists working together with NGOs, community leaders and governments, may help forge a way forward with a new paradigm: ecology as if people mattered; economics as if nature mattered. When undertaken both with a practical, pragmatic bent, and a sound ethical underpinning of this paradigm, ecological restoration - linked to nature conservation and sustainability - offers a way to a different, and better future for all (Blignaut et al. in press; Milton, 
Aronson, \& Blignaut 2005). Acting to restore Nature is also the antithesis and the antidote to the thesis of ever-expanding consumption and growth, which is embedded within neo-liberal economic theories (Blignaut et al. in press). Indeed, there seems to be a growing awareness that a profound change is required, driven by the increasing perception of the global risks and challenges ahead. The obstacles loom large too - an inadequate basis in socio-ecological systems science and, above all, inertia or outright opposition in the political and economic spheres.

What can conservation and restoration scientists do? Along with our day-time jobs of advancing the frontiers of science, we can and should help cross the serious informational, ideological and political chasms that separate disciplines and are obstacles in the way of working together for a more sustainable lifestyle. In our forthcoming books, A Global Vision for Ecological Restoration (Clewell \& Aronson in prep.) and Restoring Natural Capital: Science, Business and Practice (Aronson, Milton, \& Blignaut in press), we - along with more than 70 contributors from around the world - argue that natural capital has become the limiting factor for human well-being and economic sustainability. We note that natural capital is a notion understandable by all and is highly effective in bridging the underlying paradigm divides. Ecological restoration, especially if investment in restoring natural capital is taken as the guiding principle, can contribute both to nature conservation and to sound and ethical socio-economic development and can augment the supply of ecosystem goods and services while increasing the inventory of natural areas.

The restoration of natural capital is arguably one of the most radical ideas to emerge in recent years as it links two imperatives whose exponents have been at loggerheads for decades. These are the need to protect biodiversity and conserve natural resources as espoused by conservationists and environmentalists, and the demand for natural resources as dictated by economists and society at large, at local, regional, national and international scales. But to get such a model to operate, we need to move away from the current model quickly. We need to work together, or even 'leap together', across traditional disciplinary frontiers or polemical stances, in order to find innovative solutions that counter the prevailing ideological divide separating economics and ecology as well as the perceived conflict or trade-off between economic development and the conservation of natural and environmental resources. We need to demonstrate not only that nature conservation and restoration can be profitable, but that corporations and governments can help rapidly advance environmental goals through simultaneous restoration of natural capital and social capital within communities and countries suffering poverty, joblessness, despair, illiteracy and ensuing loss of skills, dignity, self esteem, and social fibre. Social capital consists of institutions, relationships, social networks, shared cultural beliefs and traditions that promote mutual trust. We close with a proposition of five pillars and three principal tasks for sustainable living, including conservation and restoration. The five pillars are:

(1) Clear and integrated ecological and economic concepts and models.

(2) Goals based on values and ethics.

(3) Effective strategies and tools for achieving goals.

(4) Rigorous, multidisciplinary evaluation of natural and social capital restoration activities and trajectories.

(5) Socio-economic integration of projects within cultural, historical and political contexts.

The three principal tasks are:

(1) Develop and test models of combined conservation, sustainable use and ecological restoration that are applicable and appropriate across a range of biophysical, historical, and socio-cultural and economic settings and situations;

(2) Communicate and act effectively to achieve sustainable living through greater transdisciplinary and international cooperation;

(3) Restore natural capital and, concomitantly, social capital.

On this last point, we would emphasise that people working together to restore natural capital are also actively developing mutual trust and common purpose, which are cornerstones of social capital. Working 
together, we can find and apply holistic solutions to the pressing problems of people and of the rest of Nature.

In the preceding papers of this special issue, our invited authors, from diverse parts of the Earth, illustrate that the conceptual and practical boundaries among conservation, restoration, and ecosystem management are becoming increasingly blurred, even as the range of landscapes requiring study and management has become increasingly complex (Machado 2004). What emerges from a reading of all these papers is that, although there are clearly gaps in the science that need plugging, the major barrier to achieving restoration at local and global scales, is failure of society to accept the current ecological crisis or to address it fundamentally by changing economic valuation and investment. Shifting resource depletion and pollution from one part or the globe to another cannot solve, or even conceal, global-scale erosion of social and natural capital. The era of the dual global economy (north-south, developed-undeveloped) is drawing to a close. We share a single planet in need of care and repair.

\section{Acknowledgements}

This guest-edited volume of the Journal for Nature Conservation grew out of the Society for Ecological Restoration Europe and SER International's joint meeting held in September 2005, in Zaragoza, Spain. Our thanks go Paco Comin and to all the organisers of that meeting, and to our superb team of contributors. A thousand orchids go to Christelle Fontaine (CEFE/CNRS, Montpellier). Our warm thanks also go to Cathal O'Mahony, and to Silke Mehner from Elsevier, and to all 23 invited contributors to this special issue on conservation and restoration. James Aronson gratefully acknowledges support from the European Commission FP5: QLRT-2001-01594, for support of the CREAOK project during the period when this special issue was assembled. Sue J Milton's research contribution to this work was partly supported by the National Research Foundation of South Africa under Grant number 2053674. We also wish to acknowledge the support of the Bilateral Project 17370 of the French CNRS and South African NRF Cooperation Agreement, without which this project could not have been achieved.

\section{References}

Aronson, J., Milton, S. J., \& Blignaut, J. N. (in press). Restoring natural capital: Definitions and rationale. In J. Aronson, S. J. Milton, \& J. N. Blignaut (Eds.), Restoring natural capital: Science, business and practice. Washington, DC: Island Press (to appear in 2007).

Arrow, K., Bolin, B., Costanza, R., etal. (1995). Economic growth, carrying capacity and the environment. Science, 268, 520-521.

Blignaut, J. N. (2004). Towards an economic development ethic. In J. N. Blignaut, \& M. P. de Wit (Eds.), Sustainable options. Cape Town: UCT Press.

Blignaut, J. N., Aronson, J., Archer, S., Clewell, A.F., Woodworth, P., \& Desai, N. (in press). The values and ethics of restoring natural capital. In J. Aronson, S. J. Milton, \& J. N. Blignaut (Eds.), Restoring natural capital: Science, business and practice. Washington, DC: Island Press.

Clewell, A. F., \& Aronson, J. (in prep). A global vision for ecological restoration.

Dasgupta, P. (2002). Human well-being and the natural environment. Oxford, UK: Oxford University Press.

Dobson, A. P., Bradshaw, A. D., \& Baker, A. J. M. (1997). Hopes for the future: Restoration ecology and conservation biology. Science, $277,515-522$.

Heal, G. (2000). Nature and the marketplace. Washington DC: Island Press; CA:Covelo.

Kates, R. W., Clark, W. C, Corell, R., et al. (2001). Sustainability science. Science, 292, 641-642.

Machado, A. (2004). An index of naturalness. Journal for Nature Conservation, 12, 95-110.

MacMahon, J. A., \& Holl, K. D. (2001). Ecological restoration: A key to conservation biology's future. In M. E. Soule, \& G. H. Orians (Eds.), Conservation biology: Research priorities for the next decade (pp. 245-269). Washington, DC: Island Press; CA:Covelo.

Millennium Ecosystem Assessment. (2005). Ecosystems and human well-being: Synthesis. Washington, DC;: Island Press; CA:Covelo.

Milton, S. J., Aronson, J., \& Blignaut, J. N. (2005). Restoring natural capital - Shared visions for ecology and economy. Quest (South African Academy of Science), 2(1), 39--41.

Saul, J. R. (2005). The collapse of globalism and the reinvention of the world. Woodstock, NY: The Overlook Press. 
Wackemagel, M., \& Rees, W. E. (1997). Perceptual and structural barriers to investing in natural capital: Economics from an ecological footprint perspective. Ecological Economics, 20, 3-24.

Young, T. (2000). Restoration ecology and conservation biology. Biological Conservation, 92, 73-83. 